DOI: $10.18196 /$ st. 211210

\title{
Kajian Angkutan Sedimen Di Sungai Pabelan, Kabupaten Magelang, Jawa Tengah
}

\author{
(Study of Sediment Transport at Pabelan River, Magelang Regency, Central Java)
}

\author{
RISKY FAUZIYAH, BAMBANG AGUS KIRONOTO, DJOKO LEGONO
}

\begin{abstract}
Pabelan River is one of the rivers in the western slopes of mount Merapi located in Magelang Regency, Central Java province. Pabelan River has watersheds $\pm 84,70$ $\mathrm{km}^{2}$ with the main river length $\pm 28,40 \mathrm{~km}^{2}$. The purpose of this research was to estimate the amount of sediment transport that occurred at the point of view in the Pabelan River and to know estimate of sediment balance that occurred at the point of view in the Pabelan River. This research was conducted to find out the sediment balance in the Pabelan River whether going on degradation, aggradation, or experience the equilibrium transport. Calculation of sediment balances based on the volume of sediment transport entering at the location selected. Based on the results of sediment transport analysis using MPM, EINSTEIN, DU BOYS and ROTTNER formula, the largest sediment transport volume occurred in PA-C $5=4850,592$ $\mathrm{m}^{3} / \mathrm{m} /$ flood, 305,8398 $\mathrm{m}^{3} / \mathrm{m} /$ flood, 20321,979 $\mathrm{m}^{3} / \mathrm{m} /$ flood and 80274,221 $\mathrm{m}^{3} / \mathrm{m} /$ flood, while the result of calculation based on formula FRIJLINK largest sediment transport volume occurred at PA-C $3=3654,817 \mathrm{~m}^{3} / \mathrm{m} / \mathrm{flood}$. To obtain the result of equilibrium sediment that occurred in the river of research is by using the five formula with the condition of the river that occurred aggradation and degradation with the biggest condition is the result of calculation with the formula ROTTNER for aggradation occurs in PA-C X Prumpung amount of 47272,806 $\mathrm{m}^{3} / \mathrm{m} / \mathrm{s}$ with increase river bed amount of $13,504 \mathrm{~m}$ and degradation occurred at PAC $5-47468,692 \mathrm{~m}^{3} / \mathrm{m} / \mathrm{s}$ with decrease at river bed $-23,698 \mathrm{~m}$.
\end{abstract}

Keywords: Sediment transport, sediment balance, and volume of sediment

\section{Pendahuluan.}

Sungai Pabelan adalah salah satu sungai di barat lereng gunung Merapi yang terletak di kabupaten Magelang, Provinsi Jawa Tengah. Sungai Pabelan mempunyai Daerah Aliran Sungai $(D A S) \pm 84,40 \mathrm{~km}^{2}$ dengan panjang sungai utama $\pm 28,40 \mathrm{~km}^{2}$. Pada bagian selatan Sungai Pabelan berhulu di gunung Merapi terdapat tiga anak sungai yaitu, Sungai Trising, Sungai Apu, dan Sungai Senowo sedangkan pada bagian utara Sungai Pabelan berhulu di gunung Merbabu. Pasca erupsi tahun 2010 gunung Merapi menghasilkan aliran piroklastik, lava dan lahar yang menimbulkan daya rusak yang cukup besar dan mengancam jiwa manusia terutama yang berada di sekitar alur sungai.

Pasca erupsi gunung Merapi tahun 2010 di bagian hulu Sungai Pabelan tertutup oleh endapan material piroklastik sehingga terbentuknya aliran lahar yang mempengaruhi keseimbangan sungai. Permasalahan dari penelitian ini untuk mengetahui keseimbangan sedimen di sungai pabelan apakah terjadi penggerusan (degradation), pengendapan (aggradation), atau mengalami angkutan yang seimbang (equilibrium transport).

Perubahan geomorfologi akibat angkutan sedimen dari hulu ke hilir yang bervariasi akan mengakibatkan perubahan pada dasar sungai dan adanya campur tangan manusia di sepanjang aliran sungai seperti pembangunan penahan sedimen (check dam) dan seperti kegiatan penambangan pasir secara berlebihan sehingga menyebabkan terganggunya suplai sedimen dari hulu ke hilir sehingga menyebabkan perubahan dasar sungai. Daerah yang akan di tinjau pada penelitian ini adalah daerah aliran sungai (DAS) Sungai Pabelan, terdapat 6 titik tinjauan yaitu pada ruas PA-C 1 Banyudono di desa Krogowanan sampai dengan PA-CX Prumpung di desa Sidoharjo dapat dilihat pada Gambar 1 dan Gambar 2 berikut. 


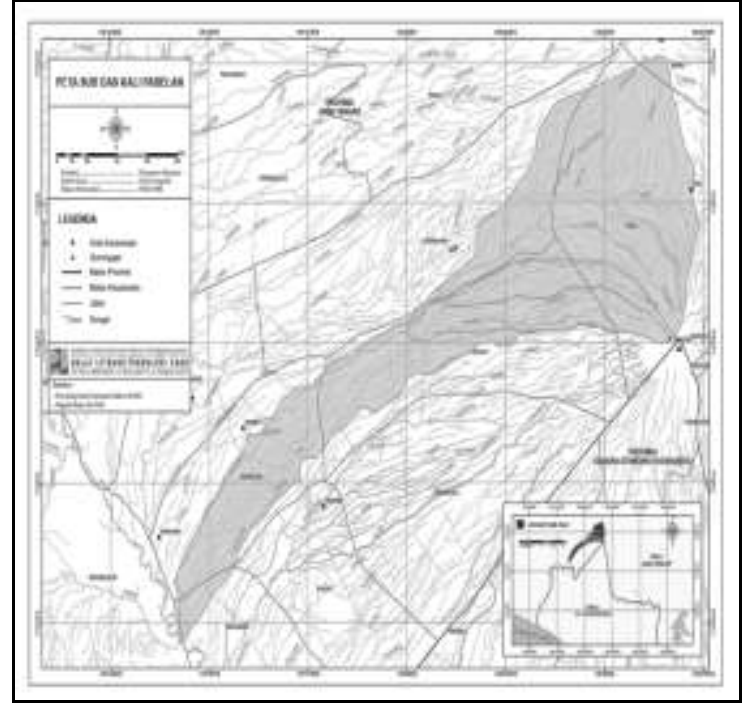

GAMBAR 1. Daerah Aliran Sungai Pabelan

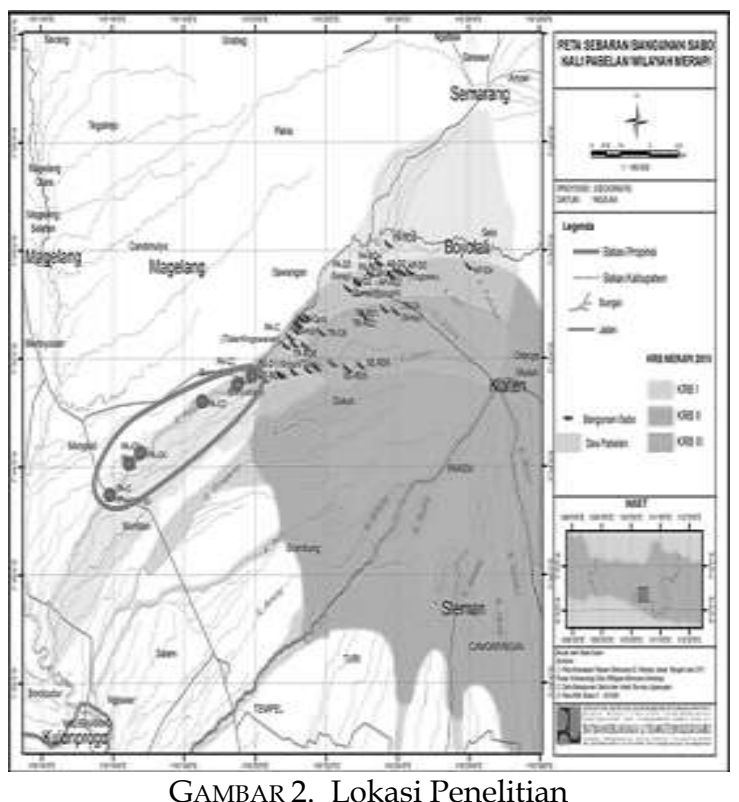

Pembahasan yang dilakukan dalam penelitian ini terbatas pada Sungai Pabelan yang yang meninjau enam titik tinjauan yaitu pada ruas PA-C 1 Banyudono (Krogowanan), PA-C 2 Banyudono (Sawangan), PA-C 3 (Sawangan), PA-C 4 (Mungkid), PA-C 5 (Mungkid) dan PAC X Prumpung (Sidoharjo).

\section{Karakteristik Angkutan Sedimen}

Angkutan sedimen merupakan interaksi antara aliran air dan material dasar saluran, sehingga merupakan proses yang kompleks.

Angkutan sedimen dapat dibedakan dari cara bergeraknya yaitu :

a. Angkutan sedimen dasar (bed load) yaitu bergerak dengan mekanisme bergeser (sliding), berguling (rolling), dan meloncat loncat (saltation) dimana untuk selang waktu yang relatif kecil tiap butiran selalu pernah berada di dasar saluran.

b. Angkutan sedimen suspensi yaitu bergerak dengan cara melayang mengikuti aliran mulai dari suatu batas dekat dasar (batas bawaah berjarak tertentu misal $D_{50}$ dari dasar) hingga permukaan aliran.

c. Wash load adalah bagian sedimen suspensi yang sangat kecil dan asalnya bukan dari material dasar, selalu bergerak dalam suspense dan selama konsentrasinya kecil biasanya dapat diabaikan dalan hitungan.

Gaya atau energy yang memberikan konstribusi terbesar adalah dari aliran air (tegangan geser) terutama untuk angkutan sedimen dasar (bed load), selanjutnya turbulensi aliran berperan dalam membentuk angkutan sedimen melayang (suspensi). (Kironoto, 2015)

1. Kondisi alur sungai

Pada saat ini maraknya akivitas penambangan pasir pada bagian hulu Sungai Pabelan, yang dimaksud dengan penambangan adalah semua kegiatan penambangan yang mana meliputi eksplorasi, eksploitasi, pengangkutan dan pengelolaan serta penjualan.

Apabila jumlah volume sedimen yang di tambang melebihi jumlah volume sedimen yang terangkut oleh banjir, maka aliran banjir yang melewati Check Dam ke hilir hanya akan membawa sejumlah kecil sedimen dan apabila suatu kapasitas atau kemampuan angkutan sedimen yang melampaui suplai sedimen dari bagian hulu sungai maka keseimbangan angkutan sedimen yang terjadi pada alur sungai dengan cara mengambil material dari dasar sungai itu sendiri pada kondisi seperti ini maka diistilahkan sungai akan mengalami degradasi (Legono, 2015).

2. Distribusi Material Dasar

Kondisi debit air yang mengalir di sungai tidaklah tetap, selalu berubah sesuai fungsi dan waktu. Kondisi aliran sungai yang tidak permanen (unsteady flow) ini menyebabkan intensitas sedimen juga akan berubah-ubah sesuai dengan perubahan debit. Diketahui bahwa Karakteristik sedimen di sepanjang sungai Pabelan, dari hulu ke hilir dapat dijelaskan sebagai berikut (Sugeng, 2003): 
a. Bagian hulu (di atas Check Dam Sengi), sedimen berasal dari erosi lahan dan erosi alur sungai, baik pada dasar dan tebing sungai serta erosi lahan dari gunung Merbabu dan hanya sedikit dari gunung Merapi karena daerah ini terdapat anak sungai yaitu sungai Apu yang berhulu di gunung Merapi.

b. Mulai dari Check Dam sengi ke hilir sampai dengan muara Sungai Pabelan di sungai Progo, sangat dipengaruhi oleh material yang berasal dari gunung Merapi berupa endapan vulkanik , karena di daerah ini terdapat dua anak sungai yang berhulu di sungai Merapi yaitu sungai Trising dan sungai Senowo.

c. Sungai Pabelan merupakan transporting material yang bersumber dari gunung Merapi ke sungai Progo.

\section{Keseimbangan Sedimen}

Mekanisme dan proses pengendalian sedimen pada bangunan penahan sedimen yang dibangun pada palung sungai berfungsi untuk mengontrol aliran sedimen pada saat terjadi banjir besar dengan cara mereduksi debit puncak sedimen. Adanya proses sedimentasi dapat menyebabkan terjadinya perubahan dasar sungai,bila angkutan sedimen dinotasikan dengan simbol q, maka pada suatu ruas sungai yang dibatasi oleh tampang 1 dan 2 akan mengalami erosi atau pengendapan, dapat dilihat besar kecilnya angkutan sedimen yang melalui 2 tampang sungai.

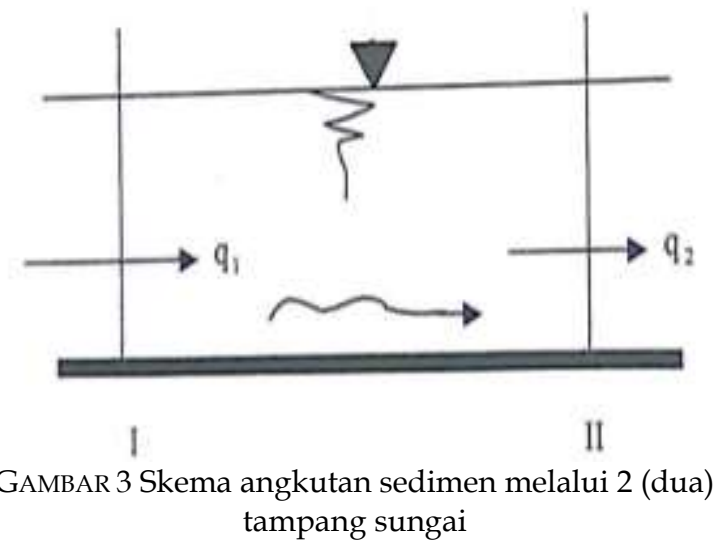

Proses angkutan sedimen yang mungkin terjadi pada dua penampang melintang sungai akibat angkutan sedimen dapat disederhanakan pada Tabel 1.
TABEL 1. Klasifikasi Proses angkutan sedimen

\begin{tabular}{ccc}
\hline Angkutan Sedimen & \multicolumn{2}{c}{ Proses Angkutan Sedimen } \\
& Sedimen & $\begin{array}{c}\text { Dasar } \\
\text { sungai }\end{array}$ \\
\hline $\mathrm{q} 1=\mathrm{q} 2$ & Seimbang & Stabil \\
$\mathrm{q} 1<\mathrm{q} 2$ & Erosi & Degradasi \\
$\mathrm{q} 1>\mathrm{q} 2$ & Pengendapan & Aggradasi \\
\hline
\end{tabular}

\section{Angkutan Sedimen.}

Dalam penelitian ini untuk mengetahui estimasi angkutan sedimen maka di lakukan analisis dengan menggunakan beberapa rumus empiris yaitu:

1. Rumus Meyer Peter Muller (1948)

Berdasarkan kondisi dilapangan yang ada di Sungai Pabelan maka perhitungan/analisis angkutan sedimen selalu dihitung dengan metode MPM. Meyer-Peter dan Muller (M.P.M) melakukan beberapa kali percobaan pada flume dengan coarse-sand, dan menghasilkan hubungan empiris antara $\Phi$ dan $\psi$ ' sebagai berikut (Priyantoro,1987):

$$
\begin{aligned}
& \Phi=\left(4 \cdot \psi^{\prime}-0,188\right)^{3 / 2} \\
& S=\Phi\left(g \cdot \Delta \cdot D m^{3}\right)^{1 / 2}
\end{aligned}
$$

Keterangan :

$\mathrm{S}=$ volume angkutan sedimen per meter lebar per satuan waktu $\left(\mathrm{m}^{3} / \mathrm{det} / \mathrm{m}\right)$

$\mathrm{Dm}=$ diameter efektif $=\mathrm{D}_{50}-\mathrm{D}_{60}$

2. Rumus Einstein (1950)

Hubungan antara kemungkinan butiran akan terangkut bed load dijabarkan sebagai berikut (Priyantoro, 1987):

$$
\begin{aligned}
& S=\Phi\left(g \cdot \Delta \cdot D_{35}^{3}\right)^{1 / 2} \\
& \Phi=0,044638+0,36249 \Psi '-0,226795 \\
& \Psi ' 2+0,036 \Psi ' 3
\end{aligned}
$$

3. Rumus Du Boys (1879)

Formula Du Boys Sebagai berikut :

$$
q s=\psi \cdot D \cdot \tau_{o}\left(\tau_{o}-\tau_{c}\right)
$$

Dimana :

qs =Debit endapan, dalam pounds per second per foot lebar saluran. $(\mathrm{kg} / \mathrm{s} / \mathrm{m})$

$\psi D=$ Suatu Koefisien dengan dimensi cubic feet per pounds per second $\left(\mathrm{m}^{3}\right.$ $/ \mathrm{kg} / \mathrm{s}$ )

$\tau_{o} \quad=\gamma . \mathrm{r} b . S_{;}$. Tegangan geser di dalam saluran dalam pounds per square per foot $\left(\mathrm{kg} / \mathrm{m}^{2}\right)$ 
$\gamma=$ Berat jenis air dalam pounds per cubic foot $\left(\mathrm{kg} / \mathrm{m}^{3}\right)$

$\mathrm{Rb}=$ Jari-jari hidrolis dalam feet; ditentukan dengan metode koreksi dinding (side-wall correction method)

$\mathrm{S}=$ Kemiringan aliran

$\tau_{c} \quad=$ Tegangan geser kritis di dasar saluran, yaitu pada saat butiran mulia bergerak $\left(\mathrm{kg} / \mathrm{m}^{2}\right)$

4. Rumus Rottner (1959)

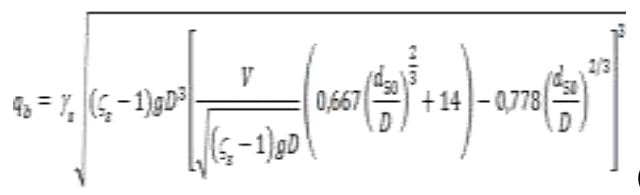

Satuan persamaan menggunakan satuan sistem British, yaitu :

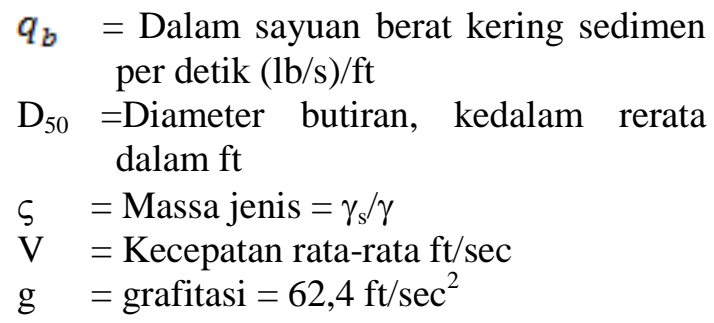

5. Rumus Frijlink

Dasar dari persamaan Frijlink adalah rumus atau persamaan dalam menghitung besaran angkutan sedimen dasar (Bed load) haruslah memperhitungkan konfigurasi dasar sungai secara khusus. Dalam hal tersebut Frijlink menjabarkan nilai Strickler dalam Rohmah, 2017 sebagai berikut:

$$
\mu=\left(\frac{I}{I^{1}}\right)=\left(\frac{K s}{K^{1} s}\right) 3 / 2
$$

\section{Dimana :}

$\mu \quad=$ Ripple factor

Ks = Nilai kekasaran butiran

K's = Koefisien akibat kekasaran butiran

\section{METODOLOGI.}

Penelitian ini dibagi menjadi empat tahap, yaitu analisis hidrologi, analisis angkutan sedimen, analisis angkutan sedimen, stabilitas butiran dan imbangan sedimen, dengan deskripsi sebagai berikut:
1. Tinjauan pustaka, persiapan perangkat, pengumpulan data primer dan sekunder data geometi, pengambilan sampel, tinjauan lapangan data spasial dan menentukan luas DAS yang berpengaruh pada titik tinjauan penelitian dan siap untuk dianalisis.

2. Analisis hidroogi:

a. Data hujan dan DAS perhitungannya menggukan metode rerata aritmatik (ArcGIS and Ms. Exel)

b. Analisis frekuensi dan uji kesesuaian distribusi untuk mendapatkan hujan rancangan dengan kala ulang 2 tahun perhitungannya menggunakan Log Pearson III Distribution, Chi-Square Test and Smirnov-Kolmogorov (Ms. Exel)

c. Hujan jam-jaman menggunakan metode Mononobe dan tutupan lahan (ArcGIS and Ms. Exel)

d. Hidrograf satuan sintesis metode Nakayasu (Ms. Exel)

e. Menghitung kapasitas angkutan sedimen dengan beberapa rumus empiris yaitu MPM, Einstein, Du Boys, Rottner dan Frijlink pada masing-masing lokasi yang ditinjau.

f. Untuk mengetahahui diameter butiran itu stabil terhadap tegangan geser yang ditimbulkan akibat adanya aliran air, maka diperlukan hitungan stabilitas butiran. Apabila tegangan geser yang ditimbulkan oleh aliran air lebih besar dari tegangan geser kritik pada butiran, maka butiran tersebut tidak stabil sehingga akan terangkut oleh aliran air.

g. Dalam penelitian ini, analisis angkutan sedimen pada kondisi debit puncak banjir dengan kala ulang 2 tahun untuk melihat bagaiman pola angkutan sedimen yang terjadi pada saat banjir dengan kondisi sesaat (jam-jaman). Dengan demikian hasil yang diperoleh hanyalah sebatas prediksi untuk mengetahui kapasitas angkutan sedimen pada setiap penampang sungai yang ditinjau. Pada kondisi ini terdapat 6 titik control yang dianalisis angkutan sedimennya,yaitu dari hulu ke hilir : PA-C 1, PA-C 2, PAC 3, PA-C 4, PA-C 5, PA-CX Prumpung.

\section{HASIL DAN PEMBAHASAN}

Untuk mengetahui fenomena angkutan sedimen yang terjadi pada kondisi debit puncak banjir pada hidrograf banjir dengan kala ulang 2 
tahun, perlu diketahui besarnya debit banjir jam-jaman. Karena tidak tersedia data debit puncak maupun data debit dominan yang terjadi pada Sungai Pabelan dengan periode pengamatan yang cukup panjang, untuk hasil penelitian dapat dilihat pada tabel berikut:

TABEL 2 Data Curah Hujan dari Tahun 2010-2015

\begin{tabular}{cccc}
\hline Tanggal & Tahun & $\begin{array}{c}\text { St.Mungkid } \\
(\mathrm{mm})\end{array}$ & $\begin{array}{c}\text { St.Sawangan } \\
(\mathrm{mm})\end{array}$ \\
\hline 22-Okt & 2010 & 126 & 82 \\
02-Jan & 2012 & 100 & 44 \\
20-Apr & 2013 & 94 & 42 \\
29-Nop & 2014 & 45 & 82 \\
02-Feb & 2015 & 63 & 95 \\
\hline
\end{tabular}

TABEL 3 Profile long cross in location selected

\begin{tabular}{ccccc}
\hline N & Lokasi & $\begin{array}{c}\text { Jarak } \\
(\mathrm{m})\end{array}$ & $\begin{array}{c}\text { Jarak } \\
\text { Komulatif } \\
(\mathrm{m})\end{array}$ & $\begin{array}{c}\text { Elevasi } \\
\text { Dasar } \\
(\mathrm{m})\end{array}$ \\
\hline 1 & PA-C 1 & 0,000 & 0,000 & 592,000 \\
2 & PA-C 2 & 992,783 & 992,783 & 540,450 \\
3 & PA-C 3 & 2084,395 & 3077,178 & 471,500 \\
4 & PA-C 4 & 3301,674 & 6378,852 & 414,790 \\
5 & PA-C 5 & 969,981 & 7348,833 & 359,000 \\
6 & PA-CX & 1702,766 & 9051,599 & 326,000 \\
\hline
\end{tabular}

Dalam penelitian ini, analisa volume sedimen yang terangkut pada kondisi banjir, dihitung dengan perbandingan dari beberapa Rumus. Rumus yang digunakan pada penelitia ini ada 5 yaitu Rumus MPM, rumus Einstein, rumus Du Boys, rumus Rottner, dan rumus Frijlink. Berdasarkan perhitungan debit banjir rancangan dengan berbagai kala ulang menghasilkan total sedimen dari masing-masing titik tinjau dapat di lihat pada tabel 4 berikut ini.

\begin{tabular}{cccc}
\multicolumn{5}{c}{ TABEL 4 Gradasi ukuran butiran material dasar } \\
Sungai Pabelan
\end{tabular}

Dalam penelitian ini, analisis angkutan sedimen pada kondisi debit puncak banjir dengan beberapa kala ulang untuk melihat bagaimana pola angkutan sedimen terjadi pada saat banjir dengan kondisi sesaat ( jam-jaman). Dengan demikian hasil yang diperoleh hanyalah sebatas prediksi untuk mengetahui kapasitas angkutan sedimen pada setiap penampang sungai yang ditinjau. Pada kondisi ini terdapat 6 titik tinjauan yang dianalisis angkutan sedimennya, yaitu dari hulu ke hilir :

Hasil analisis dengan beberapa rumus terdapat perbedaan kapasitas angkutan sedimen pada masing-masing titik tinjauan dan secara prediksi proses angkutan sedimen tersebut dapat dilihat pada nilai keseimbangan angkutan sedimen seperti pada penjabaran dibawah ini bahwa setiap titik tinjauan terdapat dasar sungai yang mengalami erosi (degradation) dan pengendapan (aggradation). Besarnya nilai erosi dan pengendapan serta proses kejadian dapat dijelaskan pada tabel 5 berikut :

TABEL 5 Hasil analisis kapasitas angkutan sedimen per siklus banjir

\begin{tabular}{|c|c|c|c|c|c|}
\hline $\mathrm{P}_{\text {Lokasi }}^{\text {Formula }}$ & $\begin{array}{c}\mathrm{Mpm} \\
\left(\mathrm{m}^{3}\right) / \mathrm{m} / \text { flood }\end{array}$ & $\begin{array}{c}\text { Einstein } \\
\left(\mathrm{m}^{3}\right) / \mathrm{m} / \text { flood }\end{array}$ & $\begin{array}{c}\text { Du Boys } \\
\left(\mathrm{m}^{3}\right) / \mathrm{m} / \text { flood }\end{array}$ & $\begin{array}{c}\text { Rottner } \\
\left(\mathrm{m}^{3}\right) / \mathrm{m} / \text { flood }\end{array}$ & $\begin{array}{c}\text { Frijlink } \\
\left(\mathrm{m}^{3}\right) / \mathrm{m} / \mathrm{flood}\end{array}$ \\
\hline PA-C 1 & 1556,0339 & 18,6714 & 15182,9340 & 11795,2635 & 6,5150 \\
\hline PA-C 2 & 3931,4832 & 214,3883 & 15088,2431 & 9503,2789 & 344,9571 \\
\hline PA-C 3 & 1024,1786 & 177,2290 & 3023,6966 & 3136,5905 & 3654,8175 \\
\hline PA-C 4 & 873,7251 & 82,6766 & 2132,4554 & 32805,5294 & 625,7262 \\
\hline PA-C 5 & 4850,5921 & 305,8398 & 20321,9796 & 80274,2214 & 828,5747 \\
\hline PA-CX Prumpung & 1027,9164 & 150,1945 & 2910,8310 & 33001,4150 & 2717,5373 \\
\hline
\end{tabular}


TABEL 6 Hasil analisis kapasitas angkutan sedimen dalam detik

\begin{tabular}{|c|c|c|c|c|c|c|}
\hline \multirow[b]{2}{*}{ No. } & \multirow[b]{2}{*}{ Lokasi } & \multicolumn{5}{|c|}{ Kapasitas angkutan sedimen } \\
\hline & & $\begin{array}{c}\mathrm{Mpm} \\
\left(\mathrm{m}^{3} / \mathrm{m} / \mathrm{s}\right)\end{array}$ & $\begin{array}{l}\text { Einstein } \\
\left(\mathrm{m}^{3} / \mathrm{m} / \mathrm{s}\right)\end{array}$ & $\begin{array}{l}\text { Du Boys } \\
\left(\mathrm{m}^{3} / \mathrm{m} / \mathrm{s}\right)\end{array}$ & $\begin{array}{l}\text { Rottner } \\
\left(\mathrm{m}^{3} / \mathrm{m} / \mathrm{s}\right)\end{array}$ & $\begin{array}{c}\text { Frijlink } \\
\left(\mathrm{m}^{3} / \mathrm{m} / \mathrm{s}\right)\end{array}$ \\
\hline 1 & PA-C 1 & 0,01801 & 0,00022 & 0,17573 & 0,13652 & 0,00008 \\
\hline 2 & PA-C 2 & 0,04550 & 0,00248 & 0,17463 & 0,10999 & 0,00399 \\
\hline 3 & PA-C 3 & 0,01185 & 0,00205 & 0,03500 & 0,03630 & 0,04230 \\
\hline 4 & PA-C 4 & 0,01011 & 0,00096 & 0,02468 & 0,37969 & 0,00724 \\
\hline 5 & PA-C 5 & 0,05614 & 0,00354 & 0,23521 & 0,92910 & 0,00959 \\
\hline 6 & PA-CX Prumpung & 0,01190 & 0,00174 & 0,03369 & 0,38196 & 0,03145 \\
\hline
\end{tabular}

TABEL 7 Rekapitulasi tebal lapisan sedimen

\begin{tabular}{ccccccc}
\hline \multirow{2}{*}{ No. } & Lokasi & $\begin{array}{c}\text { Mpm } \\
(\mathrm{m})\end{array}$ & $\begin{array}{c}\text { Einstein } \\
(\mathrm{m})\end{array}$ & $\begin{array}{c}\text { Du Boys } \\
(\mathrm{m})\end{array}$ & $\begin{array}{c}\text { Rottner } \\
(\mathrm{m})\end{array}$ & $\begin{array}{c}\text { Frijlink } \\
(\mathrm{m})\end{array}$ \\
\hline 1 & PA-C 1 & 0 & 0 & 0 & 0 & 0 \\
2 & PA-C 2 & $-1,692$ & $-0,139$ & 0,067 & 1,633 & $-0,241$ \\
3 & PA-C 3 & 0,660 & 0,008 & 2,741 & 1,446 & $-0,752$ \\
4 & PA-C 4 & 0,020 & 0,013 & 0,120 & $-4,009$ & 0,409 \\
5 & PA-C 5 & $-1,985$ & $-0,111$ & $-9,081$ & $-23,698$ & $-0,101$ \\
6 & PA-CX Prumpung & 1,092 & 0,044 & 4,974 & 13,504 & $-0,540$ \\
\hline
\end{tabular}

\section{KESIMPULAN}

Hasil analisis pada studi ini,dapat disimpulkan bahwa :

1. Metode MPM, Einstein, Du Boys, Rottner, dan Frijlink dapat mengahasilkan kapasitas angkutan sedimen disetiap titik tinjauan yaitu PA-C 1, PA-C 2, PA-C 3, PA-C 4, PAC 5, dan PA-C X Prumpung.

2. Imbangan sedimen yang terjadi di setiap titik tinjau pada Sungai Pabelan adalah dengan meninjau antara besarnya kapasitas angkutan sedimen yang masuk dengan besarnya kapasitas angkutan sedimen yang keluar, hasil dari tinjauan ini akan mendapatkan erosi maupun pengendapan. Untuk ruas sungai yang mengalami proses erosi maka dasar sungai akan terjadi degradation dan untuk ruas sungai yang mengalami pengendapan maka dasar sungai akan terjadi aggradation.

3. Setelah melakukan analisis hidrologi dengan metode Nakayasu dengan kala ulang 2 tahun dalam kurun waktu 24 jam (1 hari) maka di dapat debit puncak banjir sebesar $=40,252$ $\mathrm{m}^{3} /$ det yang mana hasil perhitungan dalam kurun waktu 24 jam di gunakan untuk menganalisa keseimbangan sedimen pada ruas PA-C 1 sampai PA-CX Prumpung, untuk mengetahui kondisi dasar sungai yang mengalami aggradation dan degradation dengan hasil sebagai berikut : dengan rumus MPM hasinya adalah 1556,034 $\left(\mathrm{m}^{3}\right) / \mathrm{m} /$ banjir, $\quad 3931,483 \quad\left(\mathrm{~m}^{3}\right) / \mathrm{m} /$ banjir, $1024,179 \quad\left(\mathrm{~m}^{3}\right) / \mathrm{m} /$ banjir, $\quad 873,725$ $\left(\mathrm{m}^{3}\right) / \mathrm{m} /$ banjir, $\quad 4850,92 \quad\left(\mathrm{~m}^{3}\right) / \mathrm{m} /$ banjir, $1027,916\left(\mathrm{~m}^{3}\right) / \mathrm{m} /$ banjir. Kemudian dengan rumus Einstein hasilnya adalah 18,671 $\left(\mathrm{m}^{3}\right) / \mathrm{m} /$ banjir, $\quad 214,388 \quad\left(\mathrm{~m}^{3}\right) / \mathrm{m} /$ banjir, $177,229 \quad\left(\mathrm{~m}^{3}\right) / \mathrm{m} /$ banjir, $\quad 82,677$ $\left(\mathrm{m}^{3}\right) / \mathrm{m} /$ banjir, $\quad 305,840 \quad\left(\mathrm{~m}^{3}\right) / \mathrm{m} /$ banjir, $150,195\left(\mathrm{~m}^{3}\right) / \mathrm{m} /$ banjir, dan dengan rumus $\mathrm{Du}$ Boys hasilnya adalah 15182,934 $\left(\mathrm{m}^{3}\right) / \mathrm{m} /$ banjir, $15088,243 \quad\left(\mathrm{~m}^{3}\right) / \mathrm{m} /$ banjir, 3023,697 $\quad\left(\mathrm{m}^{3}\right) / \mathrm{m} /$ banjir, $\quad 2132,455$ $\left(\mathrm{m}^{3}\right) / \mathrm{m} /$ banjir, $20321,980 \quad\left(\mathrm{~m}^{3}\right) / \mathrm{m} /$ banjir, 2910,831 $\left(\mathrm{m}^{3}\right) / \mathrm{m} /$ banjir. Dan dengan Rumus Rottner 11795,263 $\left(\mathrm{m}^{3}\right) / \mathrm{m} /$ banjir, 9503,279 $\left(\mathrm{m}^{3}\right) / \mathrm{m} /$ banjir, $\quad 3136,591 \quad\left(\mathrm{~m}^{3}\right) / \mathrm{m} /$ banjir, $\left.32805 \quad \mathrm{~m}^{3}\right) / \mathrm{m} /$ banjir, $\quad 80274,221$ $\left(\mathrm{m}^{3}\right) / \mathrm{m} /$ banjir, $\quad 33001,415 \quad\left(\mathrm{~m}^{3}\right) / \mathrm{m} /$ banjir. Kemudian dengan rumus Frijlink 6,515 $\left(\mathrm{m}^{3}\right) / \mathrm{m} /$ banjir, $\quad 344,957 \quad\left(\mathrm{~m}^{3}\right) / \mathrm{m} /$ banjir, 3654,817 $\quad\left(\mathrm{m}^{3}\right) / \mathrm{m} /$ banjir, $\quad 625,726$ $\left(\mathrm{m}^{3}\right) / \mathrm{m} /$ banjir, $\quad 828,575 \quad\left(\mathrm{~m}^{3}\right) / \mathrm{m} /$ banjir, $2717,537\left(\mathrm{~m}^{3}\right) / \mathrm{m} /$ banjir.

4. Setelah itu dilakukan analisis keseimbangan angkutan sedimen pada titik yang ditinjau, maka dasar sungai yang mengalami aggradation dan degradation dari PA-C 1 
sampai PA-CX Prumpung adalah : dengan rumus MPM hasilnya adalah $-1,692 \mathrm{~m}$, $0,660 \mathrm{~m}, 0,020 \mathrm{~m},-1,985 \mathrm{~m}, 1,092 \mathrm{~m}$. Kemudian dengan rumus Einstein adalah 0,139m, $-0,008 \mathrm{~m}, 0,013 \mathrm{~m},-0,111 \mathrm{~m}, 0,044$ m.Kemudian dengan rumus Du Boys hasilnya adalah $0,067 \mathrm{~m}, 2,741 \mathrm{~m}, 0,120 \mathrm{~m}$, $-9,081 \mathrm{~m}, 4,974 \mathrm{~m}$. Dan dengan rumus Rottner hasilnya adalah $1,633 \mathrm{~m}, 1,446 \mathrm{~m}$, 4,009 m,-23,698 m, 13,504 m.Dan dengan rumus Frijlink hasilnya adalah $-0,241 \mathrm{~m}$, $0,752 \mathrm{~m}, 0,409 \mathrm{~m},-0,101 \mathrm{~m},-0,540 \mathrm{~m}$.

(-) menggambarkan Terjadinya erosi (degradation) dan (+) menggambarkan Terjadinya Pengendapan (aggradation).

\section{DAFTAR PUSTAKA}

Asdak, C. (2010). Hidrologi dan pengelolaan Daerah Aliran Sungai. Yogyakarta: Gadjah Mada University Press.

Graf, W.H. (1984). Hydraulics of Sediment Transport, Mc. Graf Hill, N.Y., USA

Kironoto, B.A. (2015). Debris flow, Diktat kuliah MTPBA, Yogyakarta: UGM.

Kironoto, B.A. (1997). Hidraulika Transpor Sedimen, Pasca Sarjana, Yogyakarta: University of Gadjah Mada,

Kusumobroto, H. (2013). Aliran Debris \& Lahar Pembentukan, pengaliran dan pengendapan. Yogyakarta: Graha Ilmu.

Legono, D. (2015). Natural Disaster Damage and Loss Assesment. Diktat Kuliah MTPBA, Yogyakarta: University of Gadjah Mada.

Nizar, A. (2009). Program Transport Sedimen Pada Saluran Alluvial. Yogyakarta: University of Gadjah Mada.

Priyantoro, D. (1987). Teknik Pengangkutan Sedimen. Malang: University Brawijaya.

Rohmah, R.S. (2017). Analisis Empiris Angkutan Sedimen Sungai Progo Hilir Menggunakan Metode Meyer Peter dan Muller, Einstein, dan Frijlink. Yogyakarta: University of Muhammadiyah Yogyakarta.

Sugeng. (2003). Analisis keseimbangan dan migrasi sedimen di sepanjang kali pabelan kabupaten magelang. Yogyakarta: University of Gadjah Mada.

Soewarno. (1995). Hidrologi Aplikasi Metode Statistik untuk Analisis Data jilid 1. Bandung: Nova.

Soewarno. (2000). Hidrologi Hidrologi Operasional Jilid Kesatu. Bandung: Citra Aditya Bakti.

Soemarto. (1987). Hidrologi Teknik. Surabaya: Usaha Nasional.

Supriyatno, B. (2003). Thesis, Analisis kemampuan Bangunan Sabo Dalam Mengendalikan Sedimen di Sungai Boyong Yogyakarta. Yogyakata: University of Gadjah Mada.

Sri, H. (1993). Analisis Hidrologi. Jakarta: Gramedia.

Triatmodjo, B. (2010). Hidrologi Terapan. Yogyakarta: Beta Offset.

PENULIS:

Risky Fauziyah

Program Studi Magister Teknik Pengelolaan Bencana Alam, Fakultas Teknik, Universitas Gadjah Mada, Jalan Grafika 2 kampus UGM.

Yogyakarta 55281

Email: risky.fauziyah @gmail.com

Bambang Agus Kironoto

Program Studi Magister Teknik Pengelolaan Bencana Alam, Fakultas Teknik, Universitas Gadjah Mada, Jalan Grafika 2 kampus UGM.

Yogyakarta 55281

Email: kironoto@ugm.ac.id

Djoko Legono

Program Studi Magister Teknik Pengelolaan Bencana Alam, Fakultas Teknik, Universitas Gadjah Mada, Jalan Grafika 2 kampus UGM. Yogyakarta 55281

Email: djokolegono@ugm.ac.id 